\title{
BASP1 Gene
}

National Cancer Institute

\section{Source}

National Cancer Institute. BASP1 Gene. NCI Thesaurus. Code C113638.

This gene may be involved in neurite outgrowth. 